\title{
Pemanfaatan Kulit Jagung sebagai Bahan Cenderamata pada Daerah Pariwisata Salibutan
}

\author{
Rahmi Wizal ${ }^{1}$, Alfurqan², Amri Amir ${ }^{3}$ \\ ${ }^{1}$ Universitas Negeri Padang, rahmiwiza@fis.unp.ac.id \\ ${ }^{2}$ Universitas Negeri Padang, alfurqan@fis.unp.ac.id \\ ${ }^{3}$ Universitas Negeri Padang, amriamir0502@gmail.com
}

2021 by the authors. Submitted for possible open access publication under the terms and conditions of the Creative Commons Attribution-ShareAlike 4.0 International License-(CC-BY-SA) (https://creativecommons.org/licenses/by-sa/4.0/)

do) DOI: http://dx.doi.org/10.30983/dedikasia.vli2.5035

\begin{tabular}{|c|c|}
\hline ARTICLE INFO & ABSTRACT \\
\hline $\begin{array}{l}\text { Submit } \quad: 25 \text { Juli } 2021 \\
\text { Revised }: 28 \text { November } 2021 \\
\text { Accepted }: 30 \text { Desember } 2021 \\
\text { Keywords: } \\
\text { Corn Husks; Tourist; Salibutan(kulit } \\
\text { jagung; pariwisata; salibutan). }\end{array}$ & $\begin{array}{l}\text { Nagari Salibutan has a tourist attraction called the Nyarai } \\
\text { waterfall, which is visited by many local and foreign tourists. } \\
\text { One of the efforts to increase tourism is by making souvenirs } \\
\text { that function as souvenirs, reminder media and promotion of } \\
\text { tourist attractions. Materials in making souvenirs are obtained } \\
\text { from corn husks which are corn agricultural waste that has not } \\
\text { been used optimally, with a land area of } 10 \text { ha producing } 2 \\
\text { tons/ha of corn and its waste. With the use of corn husks, it can } \\
\text { help the community in managing waste products optimally and } \\
\text { reduce the high capital needed for souvenir raw materials. The } \\
\text { training activities were carried out by providing knowledge } \\
\text { about corn husk processing, discussions and the practice of } \\
\text { making souvenirs using pattern making techniques, twisting } \\
\text { and interlacing techniques. From the training carried out, } \\
\text { trainees gain new knowledge, motivation and development of } \\
\text { creativity in making souvenirs. The products produced in the } \\
\text { training on making souvenirs made from corn husks are } \\
\text { flowers, flower vases, key chains, wallets and bags. This } \\
\text { product can not only be marketed directly at tourism sites but } \\
\text { can also be marketed through online media. }\end{array}$ \\
\hline
\end{tabular}

Keywords: Souvenirs; Corn Husks; Tourist; Salibutan

Nagari Salibutan memiliki objek wisata bernama air terjun nyarai, banyak dikunjungi oleh wisatawan lokal dan mancanegara. Salah satu upaya dalam meningkatkan pariwisata adalah dengan pembuatan cenderamata yang berfungsi sebagai oleh-oleh, media pengingat dan promosi tempat wisata. Bahan dalam pembuatan cenderamata diperoleh dari kulit jagung yang merupakan limbah hasil pertanian jagung yang belum dimanfaatkan secara maksimal, dengan luas tanah $10 \mathrm{Ha}$ menghasilkan 2 ton/Ha jagung beserta limbahnya. Dengan pemanfaatan kulit jagung dapat membantu masyarakat dalam pengelolaan hasil limbah secara maksimal dan menekan modal yang tinggi terhadap kebutuhan bahan baku cenderamata. Kegiatan pelatihan dilaksanakan dengan pemberiaan pengetahuan seputar pengolahan kulit jagung, diskusi dan praktek pembuatan cenderamata dengan teknik pembuatan pola, teknik pilin dan jalin. Dari pelatihan yang dilaksanakan, peserta pelatihan mendapatkan pengetahuan baru, motifasi dan pengembangan kreatifitas dalam pembuatan cenderamata. Produk yang dihasilkan dalam pelatihan pembuatan cenderamata berbahan baku kulit jagung berupa bunga, vas bunga, gantungan kunci, dompet dan tas. Produk ini tidak hanya dapat dipasarkan langsung ditempat pariwisata namun juga dapat dipasarkan melalui media online. 
Kata Kunci: cenderamata; kulit jagung; pariwisata; salibutan

International License-(CC-BY-SA)

(https://creativecommons.org/licenses/by-sa/4.0/)

This is an open access article under the CC-BY-SA license

\section{Introduction}

Nagari Salibutan merupakan salah satu nagari/desa yang terdapat di Kecamatan Lubuk Alung, Kabupaten Padang Pariaman, Provinsi Sumatera Barat, memiliki 4 korong yaitu Kampung Alai, Lipek Pageh, Gamaran dan Lubuk Munti dan satu objek wisata bernama Air Terjun Nyarai (Badan Pusat Statistik Kabupaten Padang Pariaman, 2020).

Air Terjun Nyarai termasuk cagar alam nasional bukit barisan I, mulai dikenal sejak tahun 2013 (Muhammad, 2018), diperkenalkan oleh Ritno Kurniawan yang merupakan anak nagari salibutan melalui akun facebook dan twitter pribadinya. Dengan air terjun setinggi delapan meter dan dikelilingi pepohonan rindang dan batu-batu yang besar ditambah dengan air jernih berwarna hijau, mengundang banyak wisatawan datang baik yang berasal dari lokal dan mancanegara seperti korea, cina, singapura, amerika, australia dan malaysia. Melihat aset wisata yang ada, maka dibutuhkan pembenahan untuk peningkatan pengelolaan manajemen objek wisata dengan cara melengkapi sarana dan prasarana yang mendukung.

\section{Literature Review}

Menurut Cohen (Saputri and Warsono, 2017), pengembangan pariwisata memberikan dampak terhadap kondisi ekonomi masyarakat lokal dan dikategorikan sebagai berikut:

1. Dampak terhadap penerimaan devisa.

2. Dampak terhadap pendapatan masyarakat.

3. Dampak terhadap kesempatan kerja.

4. Dampak terhadap harga-harga.

5. Dampak terhadap distribusi manfaat/ keuntungan

6. Dampak terhadap kepemilikan dan control

7. Dampak terhadap pembangunan pada umumnya

8. Dampak terhadap pendapatan pemerintah

Sumber Daya Manusia pada nagari Salibutan berjumlah 2.500 orang, mayoritas masyarakat desa memiliki profesi dibidang pertanian dan bidang perkebunan. Dari sektor 
pertanian, hasil tanaman pangan yang diolah adalah padi dengan luas tanah $50 \mathrm{Ha}$ menghasilkan 1 ton/ $\mathrm{Ha}$, dan jagung dengan luas tanah $10 \mathrm{Ha}$ menghasilkan 2 ton/Ha sedangkan terong dengan luas tanah 5 Ha menghasilkan 5 ton/Ha (Selhendrizal, 2020). Hasil pertanian yang melimpah menyebabkan limbah yang banyak dan belum dikelola oleh masyarakat secara optimal, terutama limbah jagung berupa kulit jagung.

Pada umumnya hasil limbah jagung hanya digunakan untuk pakan ternak dan belum dimanfaatkan untuk bahan lainnya, sehingga pengelolaan limbah kulit jagung masih terbatas. Pemanfaatan kulit jagung dapat digunakan sebagai bahan baku pembuatan cenderamata, dengan adanya cenderamata diharapkan dapat membantu peningkatan pariwisata dan perekonomian masyarakat sekitar.

Souvenir atau Cenderamata pada kamus The Collins Cobuild Dictionary (Collin, 2021), didefenisikan sebagai berikut: 1. a usually small and relatively inexpensive article given, kept, or purchased as a reminder of a place visited, an occasion, etc.; memento 2. a memory.

Dari pengertian tersebut terdapat beberapa kriteria pada cenderamata yaitu: a. Dari segi ukuran, relatif kecil sehingga mudah untuk dibawa dan disimpan, b. Dari segi harga, relatif murah sehingga dapat disimpan atau dihadiahkan sebagai kenang-kenangan, c. Sebagai media pengingat terhadap tempat yang dikunjungi atau kegiatan yang diikuti.

Selain kriteria tersebut, cenderamata dalam penelitian Wilkins disebutkan sebagai komponen penting dalam pengalaman wisata dan wisatawan lebih menyukai cenderamata berorientasi lokal sebagaimana dibahas oleh Darnawi dalam tesisnya (Darma, 2019).

Pemanfaatan limbah kulit jagung merupakan pilihan yang tepat sebagai bahan baku pembuatan cenderamata, selain mudah untuk didapatkan juga dapat menekan ongkos pembelian bahan baku yang digunakan dalam pembuatan cenderamata. Melihat kebutuhan akan pengembangan pariwisata dan pengelolaan limbah pertanian kulit jagung maka diperlukan pelatihan yang dapat mengedukasi masyarakat dengan praktek langsung bagaimana memanfaatkan hasil limbah secara maksimal disamping meningkatkan pariwisata dan perekoniman masyarakat.

\section{Methods}

Program pengabdian kepada masyarakat dilakukan pada bulan Maret-September 2021 di Nagari Salibutan, Kecamatan Lubuk Alung, Kabupaten Padang Pariaman. Pendekatan yang digunakan adalah pendekatan partisipatif (Sangian, Dengo, dan Pombengi, 2018). Program diawali dengan observasi awal meninjau kebutuhan masyarakat dalam pengembangan daerah pariwisata dan mencarikan solusi dalam pemanfaatan limbah jagung yang belum terkelola secara maksimal. Solusi diberikan dalam bentuk kegiatan pelatihan yang mengikutsertakan masyarakat untuk berpartisipasi langsung dalam pelatihan. 
Peserta pelatihan berjumlah 28 orang yang merupakan perwakilan dari 4 (empat) korong yang berada di nagari salibutan. Pelatihan dilakukan dengan tiga tahap, yaitu:

1. Pemberian informasi dasar pengolahan dan pembuatan cenderamata berbahan baku kulit jagung dengan metode seminar dan tanya jawab.

2. Melakukan pendampingan dengan berpartisipasi langsung dalam pelatihan pembuatan cenderamata berupa bunga, vas bunga, bros, gantungan kunci dan tas, dengan teknik pembuatan pola, teknik pilin dan jalin. Pendampingan dilaksanakan dengan membentuk beberapa kelompok kecil dan disetiap kelompok disediakan alat yang mendukung dalam pembuatan cenderamata.

3. Pengevaluasian program dengan cara memantau produk yang dihasilkan oleh peserta saat pelatihan.

\section{Results}

Kegiatan pelatihan pembuatan cenderamata berbahan baku kulit jagung terselenggara dengan lancar dan kondusif. Pelaksanaan pelatihan dapat dijelaskan sebagai berikut:

1. Pemberian informasi dasar tentang kulit jagung, berupa:

a. Informasi pengolahan kulit jagung yang masih mentah sampai menjadi bahan baku siap pakai.

Setiap tanaman jagung memiliki tongkol jagung yang lapisi oleh kulit jagung yang berlapis-lapis dan setiap lapisan memiliki ketebalan dan kelenturan yang berbeda-beda (Hasdiana, 2018). Apabila dikelompokkan, maka lapisan kulit jagung terbagi menjadi tiga lapis, yaitu lapisan luar, lapisan tengah dan lapisan dalam. Rata-rata lebar kulit jagung berkisar 10-22 cm dan panjang 18-25 cm, berwarna hijau tua, hijau muda atau hijau pucat dan putih (Hasan, Halid, and Hasdiana, 2021).

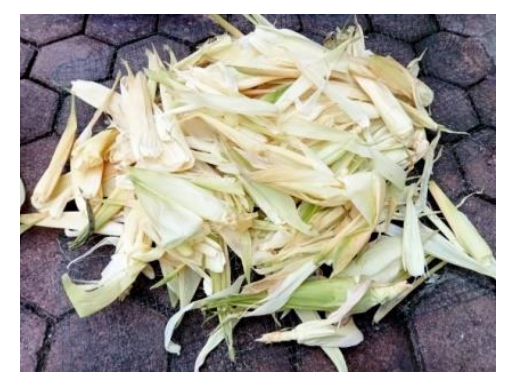

Gambar 1. Kulit jagung yang akan diolah

Tahapan dalam pengelolaan kulit jagung menjadi bahan baku cenderamata dilakukan melalui proses berikut ini:

\section{Pengupasan.}

Cara mengupas kulit jagung yang baik yaitu tidak menggunakan mesin dan dicabut secara paksa namun dikupas secara manual menggunakan pisau dengan memotong bagian 
kulit jagung dekat dengan tampuknya, sehingga didapatkan kulit jagung yang utuh dan lebar. Hal ini sangat bermanfaat dalam pembuatan produk berupa bunga dan daun yang membutuhkan media pencetakan pola yang lebar dan panjang.

\section{Pemilahan.}

Kulit jagung yang dipilih harus bersih dari kotoran dan ulat, penentuan kriteria pemilahan kulit jagung yang cocok untuk pembuatan bros dan bunga adalah kulit jagung yang agak keras dan tebal, sedangkan yang agak lunak untuk pembuatan vas bunga, tas dan dompet.

\section{Pencucian.}

Pencucian kulit jagung sebelum diolah menjadi bahan baku dibersihkan dengan air secara berulang-ulang, hal ini sangat diperlukan karena selain kulit jagung tampak bersih juga menghindari efek gatal ketika kulit jagung disentuh (Novi Darmayanti, Febrianti, and Lestari, 2020).

\section{Pewarnaan.}

Pewarnaan kulit jagung dilakukan dengan pencampuran air dan pewarna tekstil atau pewarna makanan, tingkat kepekatan warna berdasarkan kebutuhan dalam pembuatan cenderamata. Pewarnaan dapat dengan cara direbus atau direndam selama 30 menit.

\section{Pengeringan.}

Kulit jagung yang telah dicuci dan diwarnai kemudian dijemur dibawah sinar matahari, sebaiknya pada jam 09.00 - 12.00 WIB atau diangin-anginkan saja, hal ini bertujuan agar kulit jagung terjaga elastifitasnya. Penjemuran tidak dengan cara menumpuk kulit jagung pada tempat yang beralas saja, namun dipisahkan perhelainya agar pengeringan terjadi dengan sempurna.

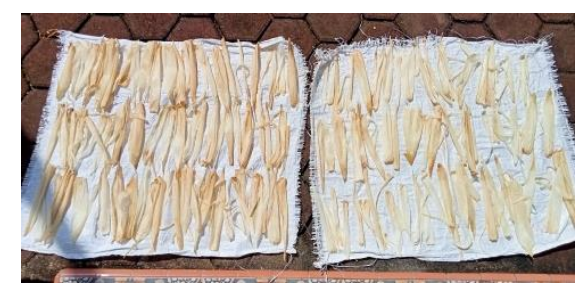

Gambar 2. Pengeringan kulit jagung dipisahkan perhelainya

Setelah kering kemudian disetrika dengan suhu 30 C/ suhu sedang (Ginting, 2015), hal ini dilakukan agar kulit jagung tidak rentan robek. Untuk pembuatan cenderamata dalam bentuk bunga dan daun, kulit jagung yang disetrika memudahkan dalam pencetakan pola. Khusus untuk pembuatan produk tas dan dompet, kulit jagung yang kering tidak perlu disetrika. Setelah semua tahapan dilakukan, maka kulit jagung siap digunakan sebagai bahan baku cenderamata. 


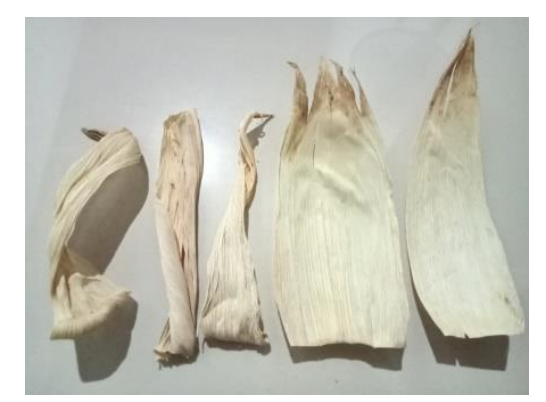

Gambar 3. Keadaan kulit jagung sebelum dan setelah disetrika.

b. Informasi pemasaran penjualan cenderamata berbahan baku kulit jagung.

Menurut Kotler dalam memasarkan produk terdapat beberapa hal yang harus diperhatikan (Rahajeng, 2018), yaitu: Product, produk yang dihasilkan harus berkualitas, memiliki design/ model serta ukuran yang sesuai sehingga menimbulkan daya tarik pembeli. Price, harga produk ditentukan berdasarkan model, ukuran dan tingkat kesulitan dalam pembuatannya. Promotion, cara menyampaikan produk pada pembeli. Place, alur distribusi, lokasi, transportasi dll. Dari kriteria yang diungkapkan maka penentuan harga sebuah produk berdasarkan pada design, kerumitan dalam pengerjaan dan waktu yang dibutuhkan dalam penyelesaian sebuah produk.

Penjualan produk dapat dilakukan dengan 2 alternatif yaitu penjualan secara offline dan online. Penjualan offline dengan memasarkan langsung di tempat wisata, sedangkan penjualan online dapat melalui web, online shop yang ada di facebook dan instagram, dan market place seperti di shopee, tokopedia, blibli, lazada, buka lapak dan juga dapat dilakukan di tiktok.

Untuk informasi penjualan, secara online kulit jagung kering dan sudah disetrika namun belum dibentuk, dijual dengan harga Rp. 1.000,-/helai sedangkan yang sudah diwarnai Rp. 1.500-4.000/helai tergantung kepada lebar kulit jagung kering yang dijual. Sedangkan kulit jagung yang sudah dibentuk menjadi buanga buatan, vas bunga, bros, gantungan kunci, dompet dan tas memiliki harga yang berfariasi, mulai dari harga Rp. 3.000 sampai ratusan ribu rupiah.

2. Melakukan pendampingan dengan berpartisipasi langsung dalam pelatihan pembuatan cenderamata.

Setelah pemberian informasi tentang kulit jagung, dilanjutkan dengan praktek pembuatan cenderamata dengan cara pendampingan langsung pada beberapa kelompok kecil dan disetiap kelompok disediakan alat yang dibutuhkan dalam pembuatan cenderamata. 

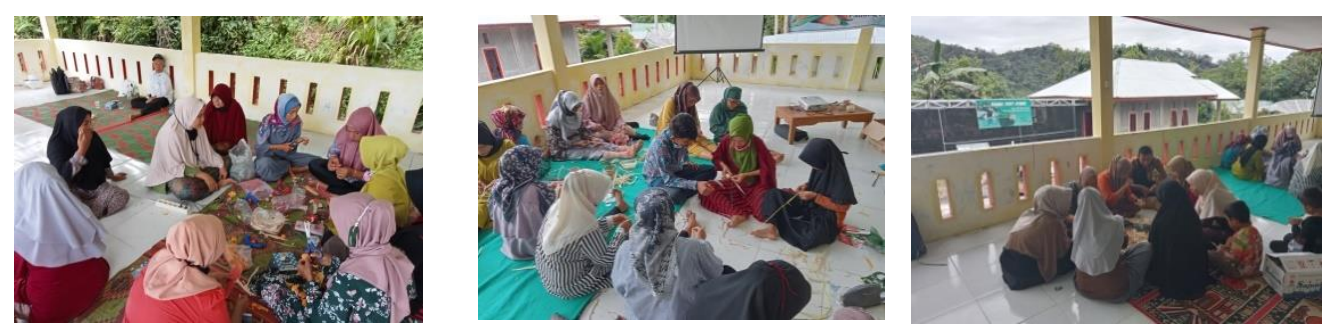

Gambar 4. Pendampingan pembuatan cenderamata dalam kelompok kecil

Peralatan yang digunakan dalam pembuatan cenderamata dari kulit jagung seperti: dawai, floral tape, tang potong, pisau, penggaris, floral foam, gunting, lem tembak, lem kayu, glue gun, jarum jahit, benang jahit, benag nilon, kain untuk pooring, resleting dan tali kur. Khusus untuk pembuatan vas bunga, dompet, tas dan tempat tatakan membutuhkan air sebagai pelembab alami pada kulit jagung yang kering sehingga teknik pilin dan jalin dalam pembuatan produk mudah dilakukan.

Produk yang dihasilkan dalam pembuatan cenderamata dilakukan dengan tiga macam cara, yaitu:

\section{Pencetakan pola.}

Bunga dari kulit jagung dibuat dengan cara menggabungkan beberapa kulit jagung yang digunting sesuai pola, pencetakan pola pada kulit jagung dilihat berdasarkan serat pada kulit jagung. Pola bunga yang sudah jadi dapat dirangkai menjadi bunga buatan (artifial) yang mirip dengan bunga asli, bunga ini bisa dijadikan bros dan mainan kunci.
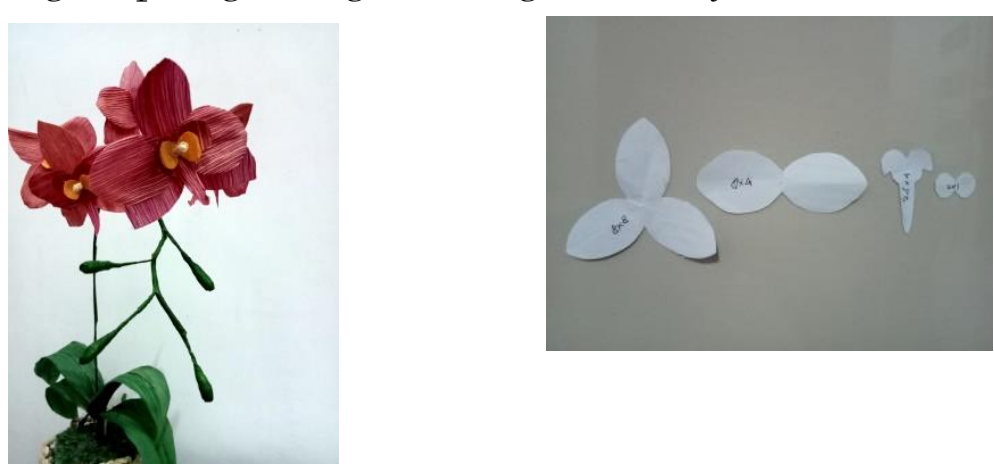

Gambar 5. Produk dalam bentuk bunga anggrek dan pola pembuatan bunga

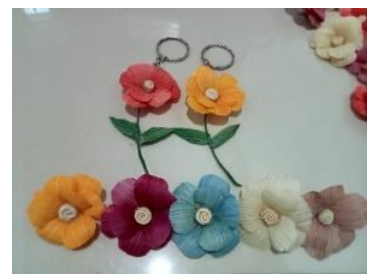

Gambar 6. Produk bunga yang dikreasikan menjadi bros dan mainan kunci

Teknik pilin. 
Pembuatan produk dompet, tas mini dan keranjang kecil, dibuat dengan menggunakan teknik pilin. Caranya dengan menggabungkan beberapa kulit jagung kemudian dipelintir secara melingkar. Kulit jagung yang kering harus dibasahi dengan air terlebih dahulu agar lebih elastis dan mudah dalam membentuk produk. Setelah menjadi produk kemudian di jemur kembali untuk mengeringkan kandungan air yang masih ada saat proses pembuatan.

Setelah produk terbentuk, khusus untuk tas dan dompet dibutuhkan kain untuk membuat puring, bagian penutup tas atau dompet dapat difariasikan dengan resleting atau tali kur.
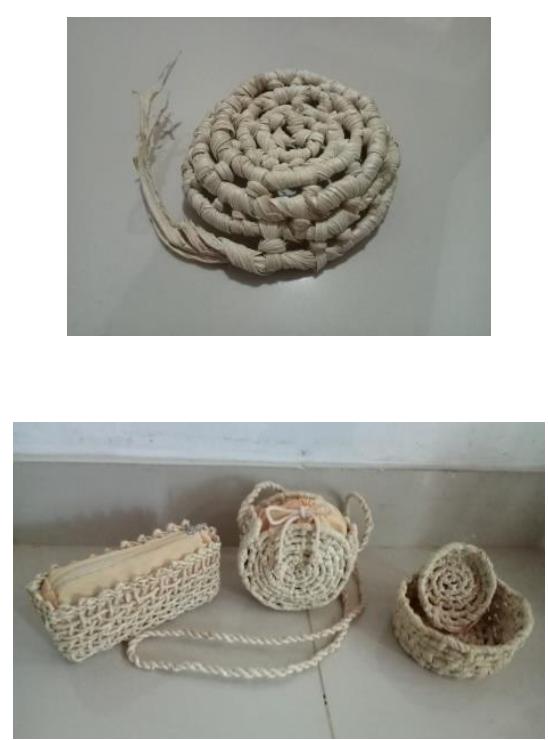

Gambar 7. Teknik pilin dan hasil produk

\section{Teknik pilin dan jalin.}

Untuk pembuatan vas bunga, tali tas dan tatakan gelas menggunakan teknik pilin dan jalin. Caranya dengan membuat dua buah kulit jagung yang telah dipelintir (tenik pilin) kemudian keduanya disatukan dengan cara dijalin.

Kulit jagung yang digunakan sebaiknya juga dibahasi terlebih dahulu dengan air, agar tidak kaku dan robek dalam membentuknya, kemudian dijemur untuk mengeringkan kandungan air yang masih ada.
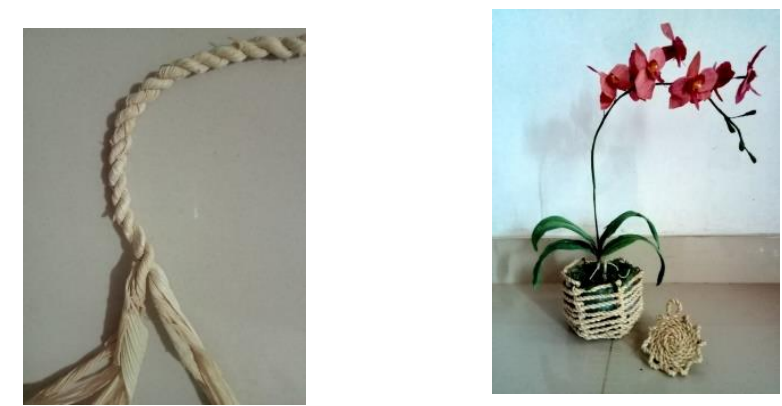

Gambar 8. Teknik pilin dan jalin serta produk yang dihasilkan (vas bunga dan tatakan gelas) 
Dalam pembuatan cenderamata yang merupakan kerajinan tangan, harus memperhatikan beberapa hal sehingga memiliki daya tarik dan manfaat, sebagaimana yang ditulis oleh Paresti (Paresti et al., 2017):

Kegunaan (Utility), produk yang dihasilkan harus memiliki nilai praktis sehingga dapat difungsikan sesuai dengan kebutuhan.

Kenyamanan (Confortable), produk tersebut harus memberikan rasa nyaman dan menyenangkan bagi pemakainya.

Keluwesan (Flexibility), produk yang dihasilkan juga harus memiliki keserasian antara bentuk dan nilai gunanya.

Keamanan (Safety), hal penting lainnya adalah tidak terdapat zat yang berbahaya pada produk.

Keindahan (Aestetic), produk yang indah memiliki daya tarik dan bernilai lebih dibandingkan produk yang biasa-biasa saja, keindahan bisa dilihat dari segi bentuk, bahan baku dan keunikan dalam proses pembuatannnya.

Dengan memperhatikan faktor tersebut, cenderamata memiliki nilai manfaat yang lebih banyak dan bukan hanya sebagai kenang-kenangan semata.

\section{Discussion}

Dalam pelatihan pembuatan cenderamata, masyarakat Salibutan sangat antusias mengikuti pelatihan sampai selesai, karena pelatihan pembuatan cenderamata dari kulit jagung belum pernah dilakukan sebelumnya dan masyarakat belum mengetahui pengelolaan kulit jagung yang dapat dijadikan sebagai bahan alternatif dalam pembuatan cenderamata. Sebelum pelatihan, kulit jagung yang marupakan hasil limbah pertanian hanya digunakan sebagai pakan ternak dan sisanya dibakar.

Setelah pelatihan dilaksanakan, peserta pelatihan yang merupakan ibu PKK dari 4 (empat) korong nagari Salibutan mendapatkan informasi yang dapat digunakan dalam pengelolaan limbah jagung secara maksimal, bukan saja menambah kreatifitas masyarakat juga membantu perekonomian dan perkembangan pariwisata.

Jika dilihat dari tingkat kebutuhan terhadap peralatan pembuatan cenderamata, maka pembuatan bunga yang dapat dijadikan bunga buatan, bros dan gantungan kunci membutuhkan alat pendukung yang lebih banyak dibandingkan pembuatan dompet, vas bunga dan tas. Namun dalam penggunaan waktu pembuatan hasil akhir produk cenderamata, pembuatan bunga, bros dan gantungan kunci relatif lebih cepat diselesaikan dibandingkan pembuatan vas bunga, dompet dan tas mini. Hal ini terlihat dari evaluasi berdasarkan tanggapan peserta pelatihan. 


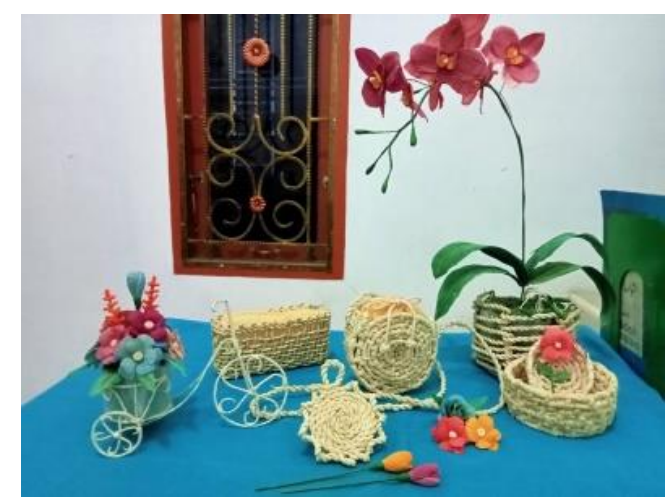

Gambar 8. Beberapa produk akhir cenderamata dari bahan baku kulit jagung

\section{Placement of Table and Figure}

Peserta pelatihan mendapatkan informasi baru yang mendukung dalam pengelolaan kulit jagung sebagai bahan cenderamata. Untuk mengetahui tingkat pemahaman dan ketercapaian tujuan dalam pelatihan pembuatan cenderamata ini, maka evaluasi dilakukan dengan cara mengumpulkan tanggapan dan melihat proses serta produk yang dihasilkan oleh peserta pelatihan.

Berdasarkan tingkat pemahaman peserta terhadap informasi tentang pengelolaan kulit jagung dapat disimpulkan sudah baik, kendala yang dihadapi adalah tingkat kesulitan dalam menyelesaikan produk cenderamata, sebagaimana tergambar pada diagram berikut:

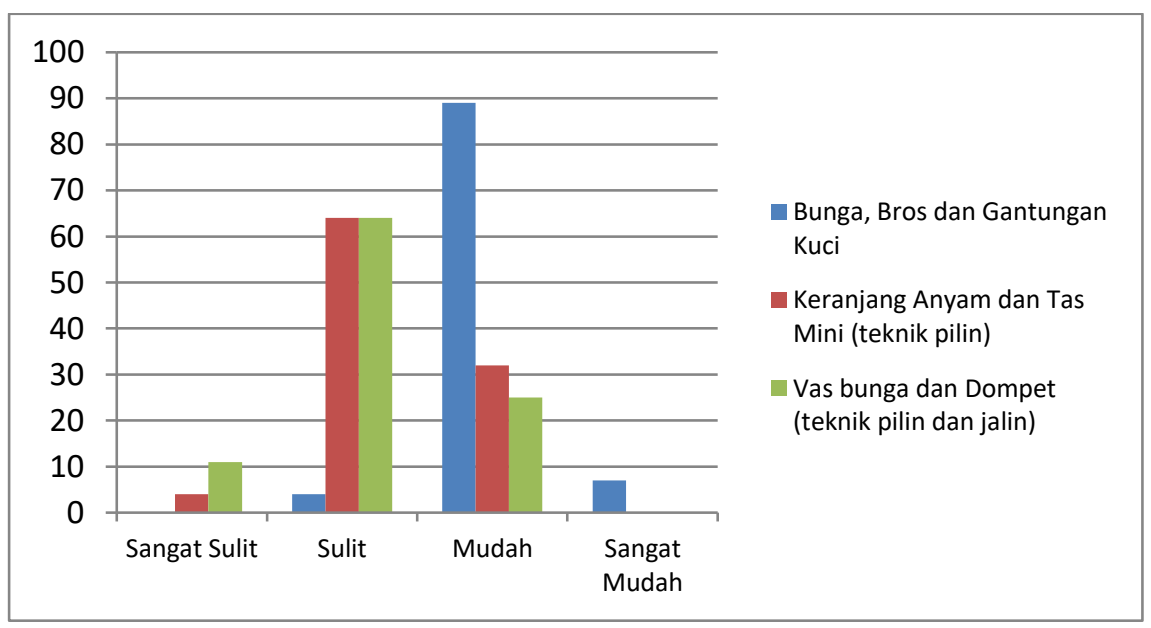

Gambar 9. Persentase pemahaman dan kemampuan peserta dalam menyelesaikan produk

Dari diagram terlihat, peserta pelatihan yang telah memahami teknik dasar dalam pembuatan kulit jagung menjadi cenderamata memiliki tingkat penyelesaian produk yang berbeda. Dari pembuatan bunga, bros dan gantungan kunci, pendapat yang dominan sebanyak $89 \%$ yang berarti peserta dengan mudah menyelesaikan produk, tanpa menghadapi kendala atau kesulitan yang berarti. 
Sedangkan dalam pembuatan produk keranjang anyam dan tas mini, pendapat dominan menyatakan mengalami kesulitan pada awalnya sebanyak 64\%, dan $32 \%$ dengan mudah menyelesaikan produk, namun hal ini tidak menjadi kendala setelah terbiasa menggunakan teknik pilin dalam pembuatan cenderamata.

Adapun dalam pembuatan produk vas bunga dan dompet dengan menggunakan teknik pilin dan jalin, berdasarkan pendapat dominan sebanyak 64\% mengalami kesulitan dan $11 \%$ sangat kesulitan menyelesaikan produk karena belum terbiasa dengan penggabungan dua teknik yaitu pilin dan jalin. Penggabungan kedua teknik membutuhkan ketekunan dan kesabaran dari peserta dalam menyelesaikan produk sampai peserta menemukan teknik mandiri yang mudah dan terbiasa dalam melakukannya.

\section{Conclusion}

Dari pelatihan pembuatan cenderamata dengan pemanfaatan limbah berupa kulit jagung yang telah dilakukan menunjukkan bahwa :

1. Salah satu solusi dalam pengembangan daerah wisata dapat dengan melakukan kegiatan pelatihan pembuatan cenderamata dengan bahan baku yang ramah lingkungan, sehingga masyarakat dapat berfikir kreatif untuk memanfaatkan hal-hal yang ada disekitarnya, terutama memaksimalkan hasil limbah pertanian karena mayoritas masyarakat salibutan bermata pencarian bertani.

2. Pemberian informasi dan beberapa teknik dalam pengelolaan kulit jagung menjadi solusi dalam pemanfaatan limbah jagung secara maksimal dan menjadi modal dasar peserta setelah pelatihan untuk melakukannya secara mandiri.

3. Pembuatan pola, teknik pilin dan jalin adalah beberapa teknik dalam pembuatan cenderatama. Tujuan inti dari cenderamata bukan hanya sebagai media pengingat dan promosi tempat wisata, namun juga memiliki nilai fungsi bagi pemiliknya. Ketekunan, kesabaran dan kreatifitas serta rasa seni yang tinggi dalam menyelesaikan produk cenderamata merupakan beberapa hal yang sangat dibutuhkan.

\section{Bibliography}

Badan Pusat Statistik Kabupaten Padang Pariaman. (2020). Kecamatan Lubuk Alung Dalam Angka.

Darma, I. G. K. I. P. (2019). Peranan Painting Bali sebagai Cendramata Khas Bali. Jurnal Pariwisata Budaya, 4(2).

Ginting, A. (2015). Pemanfaatan Limbah Kulit Jagung untuk Produk Modular dengan Teknik Pilin (Cornhusk Industrial Waste for Modular Product with Twisting Technique). Jurnal Dinamika Kerajinan Dan Batik, 32(1).

Hasan, A., Halid, A., \& Hasdiana, H. (2021, April 21). The Potential For Making Handicraft Products Using Corn Husk Fiber As An Alternative Raw Material. https://doi.org/10.4108/eai.25-11-2020.2306740

Hasdiana, A. (2018). Quality Improvement of Corn Husk as Raw Material for Textile Products. http://erabaru.net/iptek/80-bumilingkungan-/18915-produk- 
Leedy, P. D., \& Ormrod, J. E. (2010). Practical Research: Planning and Design (9th ed.). Pearson.

Muhammad, H. (2018). Berwisata dan berpetualang di Hutan Gamaran. https:/www.republika.co.id/berita/phtugp430/berwisata-dan-bertualang-di-hutan-gamaran

Novi Darmayanti, Febrianti, D. I., \& Lestari, S. A. P. (2020). Pemanfaatan Limbah Kulit Jagung Untuk Meningkatkan Perekonomian Di Desa Pejok Kecamatan Kepohbaru Kabupaten Bojonegoro. Ekobis Abdimas: Jurnal Pengabdian Masyarakat, 0l(0l). url: http://ejurnal.unisda.ac.id/index.php/baktikita\%0APEMANFAATAN

Paresti, S., Dewi Sri Handayani Nuswantari, Erny Yuliani, \& Samsudin, I. (2017). Prakarya. In Paper Knowledge. Toward a Media History of Documents. Kementerian Pendidikan dan Kebudayaan.

Rahajeng, A. (2018). Strategi Pemasaran Produk Suvenir Pendukung Desa Wisata Tinalah dan Program Bela Beli Kulon Progo. Jurnal Pengabdian Dan Pengembangan Masyarakat, 1(1).

Sangian, D. A., Dengo, S., \& Pombengi, J. D. (2018). Pendekatan Partisipatif dalam Pembangunan Desa Tawaang Kecamatan Tenga Kabupaen Minahasa Selatan. Jurnal Administrasi Publik, 4(56).

Saputri, R. A., \& Warsono, H. (2017). Evaluasi Dampak Sosial Ekonomi dalam Pengembangan Wisata Goa Seplawan di Kabupaten Purworejo. Journal of Public Policy and Management Review, 6(4).

Selhendrizal. (2020). Potensi Desa Salibutan Lubuk Alung. In Laporan Tahunan Nagari Salibutan. Laporan Tahunan Nagari Salibutan tanggal update 29 Desember 2020.

The Collins Cobuild Dictionary. https:/www.collinsdictionary.com/dictionary/english/souvenir diunggah tanggal 3 Oktober 2021 